\title{
Survey the Prevalence of Pediculosis Capitis and its As- sociated Risk Factors among Girls' Schools Students in Garmsar City, Semnan Province (Iran)
}

\author{
Maede Nakhostin ${ }^{1}$, Nilufar Naseri ${ }^{1}$, Marziye Moradi $^{2}$, Safiye Ghobakhloo ${ }^{{ }^{*}}$ \\ ${ }^{1}$ Department of Environmental Health, Semnan University of Medical Sciences, Semnan, Iran \\ ${ }^{2}$ Department of Epidemiology, Iran University of Medical Sciences, Tehran, Iran
}

*Corresponding author: Safiye Ghobakhloo, Department of Environmental Health, Semnan University of Medical Sciences, Semnan, Iran, Tel: 98919 1323815/Fax: 9823 33448999; E-mail: sa_ghobakhloo@yahoo.com

\begin{abstract}
:
Objective: The prevalence of head lice (Pediculus humanus capitis) is one of the prevalent infections in all ages particularly among students and has a worldwide distribution. Aim of this study was to survey the prevalence of head lice infestation and external factors affecting the distribution of P. capitis among girls' schools in Garmsar city and in the east of Semnan province (Iran) from December 2015 to March 2016.

Methods: This was a descriptive and analytic study. A total of 800 students aged 7-16 years old from 12 selected girls' school were examined for head lice. Data collection was done by standard questionnaire and physical examination of the hairs. A questionnaire concerning student's personal hygienic practices and socio-demographic characteristics was filled out. Analysis was done by Chi-square tests, using SPSS software version 18.

Results: The overall prevalence of head lice infestation in this study was $32 \%$ including $33.1 \%$ of the Primary schools and $31.3 \%$ of the guidance schools $(\mathrm{p}<0.001)$. A statistical significant association was observed between Pediculosis capitis and mothers' job and her education level, fathers' job, presence of health teacher in schools, bathing intervals, combing intervals, access to health services and school grade.

Conclusion: The study indicated that the prevalence of Pediculosis was a major concern but among the schools studied, the prevalence of head lice was slightly higher in elementary schools that are related to some factors including person characteristic and poor education. To find strategies for this issue, regarding its cultural, economic and social aspects, cooperation of different organs like ministries of education and health and also students and their parents is clearly required.
\end{abstract}

Keywords: Pediculosis prevalence; Girl students; Primary schools and guidance; Semnan province; Garmsar; Iran

\section{Introduction}

P. humanus capitis is a public health concern in many community worldwide ${ }^{[1,2]}$ (Burkhart and Burkhart 2007; Kurt et al., 2015). Pediculosis represents an emerging social problem in all parts of the world and in every race, socioeconomic status, family background, or personal habit ${ }^{[1]}$. (Burkhart and Burkhart 2007) Pediculosis capitis is an infestation caused by Pediculus humanus capitis ( $P$. h. capitis) ectoparasite are connected to human hosts during all life stage and feed on only human blood, do not have wings, could not jump and live in human hair ${ }^{[3]}$ (Eroglu et al. 2016). Moreover, head lice are more active at lower temperature and then normally live on the exposed scalp where temperature is less than within clothes ${ }^{[4]}$ (Gallardo et al. 2009). Head lice generally spread through direct transmission via head-to-head contact with an infected person or indirect transmission by sharing hairbrushes, clothing, hats, mats, towels, bed linen, clothing, combs, pillows, or other personal items of a person already infested is an indirect route for transmission ${ }^{[5,6]}$ (Rassami and Soonwera 2012 ; Soonwera 2014). Apart from causing irritation and intense itching on the scalp which may lead to secondary bacterial infections, P. humanus capitis may serve as a vector for some bacterial agents, such as Rickettsia prowazekii and Borrelia recurrent is which may cause life-threatening infections in humans ${ }^{[2]}$ (Kurt et al, 2015).
Received date: March 03, 2018

Accepted date: June 21, 2018 Published date: June 26, 2018

Citation: Ghobakhloo, S. Survey the Prevalence of Pediculosis Capitis and its Associated Risk Factors among Girls' Schools Students in Garmsar City, Semnan Province (Iran). (2018) Lett Health Biol Sci 3(1): 20- 26.

Copy Rights: (C) 2018 Ghobakhloo, S. This is an Open access article distributed under the terms of Creative Commons Attribution 4.0 International License. 
Head lice infestation is usually detected by three types of evidence: itching and inflammation of the scalp and neck, sighting of lice, and detection of eggs attached to hair shafts ${ }^{[5]}$ (Rassami and Soonwera 2012). So, the early diagnosis and treatment of this infestation is important for the control of infestation and patients' physical and psychological health. So that chronic heavy infestation among schoolchildren may lead to anemia and apparent morbidity among school children worldwide ${ }^{[7,3]}$ (Shirvani et al. 2013; Eroglu et al. 2016). Because, primary-school students are intermingled in classes and have high contact rates, transmission of $P$. h. capitis occurs frequently ${ }^{[6,3]}$ (Soonwera 2014; Eroglu et al. 2016). However, head lice are a common infection in school-age children worldwide ${ }^{[8]}$ (Gur and Schneeweiss 2009). In studies conducted by Falagas et al ${ }^{[9]}$ (2008), regarding the worldwide prevalence of lice infestation in the 21 st century, in Asia, prevalence varied from $0.7 \%$ to $59 \%$ and was higher in female and women, In Europe, prevalence varied from $0.48 \%$ to $22.4 \%$ and in Africa, prevalence varied from $0 \%$ to $58.9 \%$ and was higher in females. Average prevalence of pediculosis capitis in Asia was $15.1 \% \pm 12.8 \%{ }^{[9]}$ (Falagas et al. 2008). In high-income countries, school aged children aged 3-11 years are the most frequently affected despite therapeutic advances ${ }^{[9,10]}$ (Falagas et al. 2008; Omidi et al. 2013). According to the results of an epidemiological studies, head lice prevalence was estimated as 4.8\% (Netherlands), 35\% (Brazil), 1.2\% (Turkey), 28.8\% (Venezuela), and $29.7 \%$ (Argentina) ${ }^{[10]}$ (Omidi et al. 2013). In addition, various rates of head louse infestation from different parts of Iran have been reported. The results of studies conducted in Iran show, head lice prevalence was estimated as 6.85\% (Hamedan) ${ }^{[11]}$ (Nazari et al. 2005), 12.27\% (Bandarabbas) ${ }^{[12]}$ (Soleymanizadeh and Sharifi 2002), 4\% (Urmia) ${ }^{[13]}$ (Tappeh et al. 2012), $8 / 27 \%$ (Ardabil $^{[14]}$ (Adalatkhah et al. 2002), and 4.7\% (Sanadaj) [15] (Vahabi et al. 2012). Therefore, according to the results of studies conducted in worldwide, in the appraisal of head lice outbreak, socioeconomic and educational factors, availability of health care services, physical and environmental conditions of the residential households must be considered ${ }^{[16]}$ (Chouela et al. 1997). T his study was conducted to investigate prevalence of head lice infestation and some risk factors associated with the infestation rate such as social and economic status, gender, hair characteristics, personal hygiene, physical in girl's school students, in Garmsar of Semnan Province, Iran.

\section{Materials and methods}

\section{Study area}

Garmsar is a city in Semnan Province, Iran. It lies at $34 ! 28 ' \mathrm{~N}$ $34 \div 30 ' \mathrm{~N}$ latitude and $51 \div 52 ' \mathrm{E}-52\left\lfloor 55^{\prime} \mathrm{E}\right.$ longitude, and altitude of $1170 \mathrm{~m}$. The total geographical area of the district is $10686 \mathrm{Km}^{2}$, and it has a population of 48672 making it the $4^{\text {th }}$ biggest city in Semnan. The climate is hot and dry in summer and mild in winter with an average yearly temperature $17.4 \mathrm{C}$ and the average annual rainfall is $100 \mathrm{~mm}$ (Figure.1).

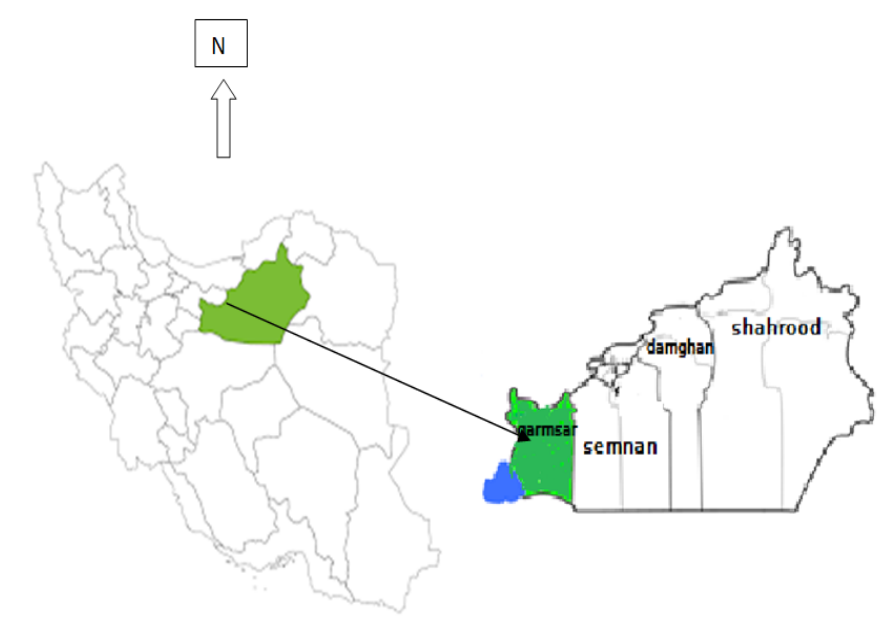

Figure 1: Garmsar city in Semnan Province, Iran

\section{Research design}

A cross-sectional descriptive study was performed from December 2015 to March 2016 among 12 girls' schools (8 primary school and 4guidance) of Garmsar, Semnan Province, Iran. Cluster sampling conducted in areas of the city was considered to form a cluster. Girls' schools were randomly selected in each cluster. A total of 800 students from first to ninth grade were examined. All examinations were carried out under permission of the teachers or the health educators. Data were obtained by the observation method and multi-stage sampling was conducted.

\section{Examination}

The examination was conducted and confirmed by at least two trained examiners under the supervision of medical entomologist. The diagnosis of head lice infestation was confirmed by clinical inspection of scalp and hair under the light of a reading lamp and by using a magnifier glass for the presence of nits and nymph or adult lice, approximately $5 \mathrm{~min}$. For the diagnosis of head lice infestation, the entire head was inspected carefully for the presence of adult lice, nymphs, or viable nits. Head lice lay nits within a few millimeters to the scalp ${ }^{[17]}$ (Frankowski 2004). Hair shafts at the back of the head and neck and behind the ears should be examined at 3 to $4 \mathrm{~mm}$ from the scalp using a finetooth comb. After the examination, the infested children were treated with herbal shampoo (anti-head lice shampoo e. g permethrin $1 \%$ and lindane $1 \%$ ).

\section{Questionnaire}

After the physical examinations a special questionnaire was completed for students. The questionnaire included socio-demographic data related to age, children's personal hygienic practices, factors that associated with head lice infestations family features and socio-economical status.

\section{Data Entry and Statistical Analysis}

The data were analyzed by SPSS software version 18 under Windows 7 , by using statistical tests including chi-squared $\left(\chi^{2}\right)$ to determine the degree of association between infestation rates with the student's age, Socio-demographic characteristics and Factors involving with head lice infestations. 
Citation: Ghobakhloo, S. Survey the Prevalence of Pediculosis Capitis and its Associated Risk Factors among Girls' Schools Students in Garmsar City, Semnan Province (Iran). (2018) Lett Health Biol Sci 3(1): 20- 26.

\section{Results}

\section{Socio-demographic characteristics}

The socio-demographic information of student is shown in Table 1. Overall, 800 students (639 Primary students and 161 Guidance students) from 12 school were recruited for P. capitis in Garmsar, located in west of Semnan. The age of the students ranged from 7 to 16 years with mean $\pm \mathrm{SD}(11.26 \pm 2.36)$ years. The majority of the participants were children who lived with parents. About $53.37 \%$ of all participants had 4 people in their family. $3 \%$ of participants were not Iranian.

\section{Prevalence of head lice infestation and related factors with} head lice infestations

Association between head lice infestations and possible factors for these infestations in 800 girls is shown in Table 1. According to the result of physical examination, the prevalence of pediculosis infestation was $32 \%$ that $34.4 \%(220 / 639)$ were found to be positive and $65.57 \%(419 / 639)$ were found to be negative in primary schools. As for guidance schools, $36.0 \%(58 / 161)$ were found to be positive and $64 \%(103 / 161)$ were found to be negative. The prevalence of head lice infestation was affected by socio-demographic factors. In this study, the effects of educational grades, educational levels of students' parents, the availability of health teachers, social and economic characteristics of families, family size and parents job, were studied on the prevalence of head lice among the school students. Although statistical test showed no significant relationship between two variables of family size and head lice, $7.19 \%$ of affected cases had family members comprising more than five persons and $53.95 \%$ of students suffering from Pediculosis living in a house with $2>$ rooms. The presence of bathroom in houses was an important issue in Pediculosis as $0.72 \%$ of the positive cases did not have a bathroom in their houses. There was no significant relationship between bath at home and pediculosis capitis. As regards the educational levels of students' parents, the students affected with head lice had parents who were illiterate or only primary of education (2.87 and $8.27 \%$, respectively). Statistical analysis showed that there was a significant relationship between pediculosis and different educational levels of students mothers $(\mathrm{P}=0.008)$ but there was no a significant relationship between pediculosis and different educational levels of students' fathers. Also there was no significant association between 'infestation prevalence (nits and lice) and the family income. There was no statistically significant association between pediculosis prevalence in students and parents job $(\mathrm{P}<0.056)$. Approximately $3.23 \%$ of students with lice whose fathers were unemployed and $75.17 \%$ fathers were employees. About $21.58 \%$ of students whose mothers were employees were infected with head lice. In this study, a significant relationship was observed between head lice infestation and mother's occupation $(\mathrm{P}=0.002)$.

\section{Factors Health Public related with head lice infestations}

Association between head lice infestations with personal characteristic in 800 girl students was shown in Table 2. Approximately $43 \%$ of students with head lice comb their hair three times per day. Roughly $29.75 \%$ of students used shared personal belongings such as hair brushes, head covers, hats and so on. There was no significant association between the infestation and shared use of personal items. In contrast, prevalence of the infestations was associated with hair length and hair style (straight or wavy) and pediculosis $(\mathrm{P}<0.025)$. On the other hand, $41.3 \%$ of students suffering from itchy scalp had pediculosis. Chi-square test between the two variables of itching of the scalp and head lice infections showed a significant relationship $(\mathrm{P}=0.033)$. About, $29 \%$ of the examined students did not have access to health teacher in schools and the prevalence of pediculosis capitis was considerable among them. Chi-square test between health teacher at the school and infestation showed significant correlation $(\mathrm{P}$ $=0.000)$.

Table 1: Prevalence of head lice infestation in 800 girl students by socio-demographic characteristics in Garmsar, Iran.

\begin{tabular}{|c|c|c|c|c|c|c|c|}
\hline \multicolumn{3}{|c|}{ Variables } & \multicolumn{5}{|c|}{ Head lice infection } \\
\hline \multicolumn{2}{|c|}{$\begin{array}{l}\text { Owner of } \\
\text { school }\end{array}$} & Governmental & $\begin{array}{l}\text { No. of } \\
\text { Non-in- } \\
\text { fected }\end{array}$ & $\%$ & $\begin{array}{l}\text { No. of } \\
\text { Infes - } \\
\text { tations/ } \\
\text { total }\end{array}$ & $\begin{array}{l}\text { Prev- } \\
\text { alence } \\
(\%)\end{array}$ & $\begin{array}{l}\mathrm{P} \\
\text { value }\end{array}$ \\
\hline \multirow{12}{*}{$\begin{array}{l}\text { sch- } \\
\text { ool } \\
\text { Gra- } \\
\text { de }\end{array}$} & \multirow{7}{*}{$\begin{array}{l}\text { Pri- } \\
\mathrm{ma}- \\
\text { ry }\end{array}$} & First & 15 & 39.5 & $23 / 38$ & 60.5 & \multirow{12}{*}{$\begin{array}{l}\mathrm{P}= \\
0.001\end{array}$} \\
\hline & & Second & 17 & 44.7 & $21 / 38$ & 55.3 & \\
\hline & & Third & 68 & 69.4 & $30 / 98$ & 30.6 & \\
\hline & & Fourth & 86 & 68.3 & $40 / 126$ & 31.7 & \\
\hline & & Fifth & 116 & 67.1 & $57 / 173$ & 32.9 & \\
\hline & & Sixth & 117 & 70.5 & $49 / 166$ & 29.5 & \\
\hline & & Sum & 419 & 66.9 & $220 / 639$ & 34.4 & \\
\hline & \multirow{5}{*}{$\begin{array}{l}\text { Mid- } \\
\text { dle }\end{array}$} & Seventh & 35 & 74.5 & Dec-47 & 25.5 & \\
\hline & & Eighth & 33 & 56.9 & $25 / 58$ & 43.1 & \\
\hline & & Ninth & 35 & 62.5 & $21 / 56$ & 37.5 & \\
\hline & & Sum & 103 & 65.2 & $58 / 161$ & 36 & \\
\hline & & Total & 522 & 67.3 & $278 / 800$ & 34.75 & \\
\hline \multirow{5}{*}{\multicolumn{2}{|c|}{ Father's job }} & $\begin{array}{l}\text { General em- } \\
\text { ployee }\end{array}$ & 142 & 69.6 & $62 / 204$ & 30.4 & \multirow[t]{5}{*}{$\begin{array}{l}\mathrm{P}= \\
0.056\end{array}$} \\
\hline & & $\begin{array}{l}\text { Company em- } \\
\text { ployee }\end{array}$ & 279 & 65.5 & $147 / 426$ & 34.5 & \\
\hline & & Farmer & 19 & 45.2 & $23 / 42$ & 54.8 & \\
\hline & & self-employed & 66 & 64.1 & $37 / 103$ & 35.9 & \\
\hline & & Unemployed & 16 & 64 & 25-Sep & 36 & \\
\hline \multirow{2}{*}{\multicolumn{2}{|c|}{$\begin{array}{l}\text { Mother's } \\
\text { job }\end{array}$}} & Housekeeper & 355 & 62 & $218 / 573$ & 38 & \multirow{2}{*}{$\begin{array}{l}\mathrm{P}= \\
0.002\end{array}$} \\
\hline & & Employed & 167 & 73.6 & $60 / 227$ & 26.4 & \\
\hline \multirow{5}{*}{\multicolumn{2}{|c|}{$\begin{array}{l}\text { Father's ed- } \\
\text { ucation }\end{array}$}} & Primary & 18 & 62.1 & 29-Nov & 37.9 & \multirow{5}{*}{$\begin{array}{l}\mathrm{P}= \\
0.758\end{array}$} \\
\hline & & Guidance & 86 & 62.3 & $52 / 138$ & 37.7 & \\
\hline & & $\begin{array}{l}\text { High school or } \\
\text { diploma }\end{array}$ & 231 & 64.5 & $127 / 358$ & 35.5 & \\
\hline & & $\begin{array}{l}\text { University ed- } \\
\text { ucation }\end{array}$ & 177 & 68.3 & $82 / 259$ & 31.7 & \\
\hline & & Illiterate & 10 & 62.5 & 16-Jun & 37.5 & \\
\hline \multirow{5}{*}{\multicolumn{2}{|c|}{$\begin{array}{l}\text { Mother's } \\
\text { education }\end{array}$}} & Primary & 22 & 64.7 & Dec-34 & 35.3 & \multirow{5}{*}{$\begin{array}{l}\mathrm{P}= \\
0.008\end{array}$} \\
\hline & & -Guidance & 70 & 56 & $55 / 125$ & 44 & \\
\hline & & $\begin{array}{l}\text { High school or } \\
\text { diploma }\end{array}$ & 282 & 64.7 & $154 / 436$ & 35.3 & \\
\hline & & University & 148 & 72.9 & $55 / 203$ & 27.1 & \\
\hline & & Illiterate & 0 & 0 & $2-\mathrm{Feb}$ & 1 & \\
\hline \multirow{2}{*}{\multicolumn{2}{|c|}{$\begin{array}{l}\text { The pres- } \\
\text { ence of a } \\
\text { bathroom at } \\
\text { home }\end{array}$}} & Yes & 522 & 100 & $276 / 798$ & 34.6 & \multirow{2}{*}{$\begin{array}{l}\mathrm{P}= \\
0.052\end{array}$} \\
\hline & & No & 0 & 0 & $2-\mathrm{Feb}$ & 100 & \\
\hline
\end{tabular}




\begin{tabular}{|c|c|c|c|c|c|c|}
\hline \multirow{5}{*}{$\begin{array}{l}\text { Number of } \\
\mathrm{f} \mathrm{a} \mathrm{m} \mathrm{i} 1 \mathrm{y} \\
\text { member } \\
\text { ( f a m i } 1 \text { y } \\
\text { size) }\end{array}$} & 2 & 5 & 55.6 & 9-Apr & 44.4 & \multirow{5}{*}{$\begin{array}{l}\mathrm{P}= \\
0.647\end{array}$} \\
\hline & 3 & 122 & 65.9 & $63 / 185$ & 34.1 & \\
\hline & 4 & 286 & 67 & $141 / 427$ & 33 & \\
\hline & 5 & 77 & 60.6 & $50 / 127$ & 39.4 & \\
\hline & $5<$ & 32 & 61.5 & $20 / 52$ & 38.5 & \\
\hline \multirow{3}{*}{$\begin{array}{l}\text { Number of } \\
\text { bedroom at } \\
\text { home }\end{array}$} & 1 & 243 & 61.8 & $150 / 393$ & 38.2 & \multirow{3}{*}{$\begin{array}{l}\mathrm{P}= \\
0.110\end{array}$} \\
\hline & 2 & 278 & 68.5 & $128 / 407$ & 31.44 & \\
\hline & 3 & 1 & 100 & - & 0 & \\
\hline \multirow{3}{*}{$\begin{array}{l}\text { Family } \\
\text { income } \\
\text { (\$/month) }\end{array}$} & $\begin{array}{l}\text { Less than } \$ \\
400\end{array}$ & 71 & 60.7 & $46 / 117$ & 39.3 & \multirow[t]{3}{*}{$\begin{array}{l}\mathrm{P}= \\
0.159\end{array}$} \\
\hline & $\begin{array}{l}\text { Between\$ } 400 \\
\text { to } \$ 650\end{array}$ & 327 & 64.4 & $181 / 508$ & 35.6 & \\
\hline & $\begin{array}{l}\text { More than } \$ \\
650\end{array}$ & 124 & 70.9 & $51 / 175$ & 29.1 & \\
\hline \multirow[t]{2}{*}{ Tap water } & Yes & 508 & 66 & $262 / 770$ & 34 & \multirow{2}{*}{$\begin{array}{l}\mathrm{P}= \\
0.029\end{array}$} \\
\hline & No & 14 & 46.7 & $16 / 30$ & 53.3 & \\
\hline
\end{tabular}

Table 2: Person characteristic related with head lice infections in 800 girl student.

\begin{tabular}{|c|c|c|c|c|c|c|}
\hline \multicolumn{2}{|c|}{ Risk characteristics } & \multirow{2}{*}{$\begin{array}{l}\mathrm{No} . \\
\text { exam- } \\
\text { ined } \\
397 \\
\end{array}$} & \multirow{2}{*}{$\begin{array}{l}\mathrm{No} . \\
\text { posi- } \\
\text { tive }\end{array}$} & \multirow{2}{*}{$\begin{array}{l}\begin{array}{l}\% \\
\text { posi- } \\
\text { tive }\end{array} \\
38.5 \\
\end{array}$} & \multirow{3}{*}{$\begin{array}{l}\mathrm{c} h \mathrm{~h}- \\
\text { squared } \\
(\chi 2)\end{array}$} & \multirow{3}{*}{$\begin{array}{l}\mathrm{P} \text { value } \\
\mathrm{P}=0.025\end{array}$} \\
\hline \multirow{2}{*}{$\begin{array}{l}\text { Hair length } \\
>10 \mathrm{~cm}\end{array}$} & Yes & & & & & \\
\hline & No & 403 & 125 & 31.0 & & \\
\hline \multirow[t]{2}{*}{ Hair Style } & Straight & 510 & 163 & 32.0 & \multirow[t]{2}{*}{18.176} & \multirow[t]{2}{*}{$\mathrm{P}=0.028$} \\
\hline & Wavy & 290 & 115 & 39.7 & & \\
\hline \multirow{2}{*}{$\begin{array}{l}\text { Itching on } \\
\text { scalp }\end{array}$} & Yes & 184 & 76 & 41.3 & \multirow[t]{2}{*}{7.358} & \multirow[t]{2}{*}{$\mathrm{P}=0.033$} \\
\hline & No & 616 & 202 & 32.8 & & \\
\hline \multirow{2}{*}{$\begin{array}{l}\text { shared per- } \\
\text { sonal be- } \\
\text { longings }\end{array}$} & Yes & 238 & 91 & 38.2 & \multirow[t]{2}{*}{3.188} & \multirow[t]{2}{*}{$\mathrm{P}=0.178$} \\
\hline & No & 562 & 178 & 33.3 & & \\
\hline \multirow[t]{4}{*}{$\begin{array}{l}\text { Combing } \\
\text { intervals }\end{array}$} & $\begin{array}{l}\text { o n c e } \\
\text { per day }\end{array}$ & 305 & 116 & 38.0 & \multirow[t]{4}{*}{36.799} & \multirow[t]{4}{*}{$\mathrm{P}=0.041$} \\
\hline & $\begin{array}{l}\text { t w i c e } \\
\text { per day }\end{array}$ & 240 & 68 & 30.0 & & \\
\hline & $\begin{array}{l}\mathrm{t} \text { h re e } \\
\mathrm{t} \text { i m e s } \\
\text { per day }\end{array}$ & 79 & 34 & 43.0 & & \\
\hline & None & 176 & 60 & 34.1 & & \\
\hline \multirow{4}{*}{$\begin{array}{l}\text { Bath inter- } \\
\text { vals }\end{array}$} & Daily & 79 & 19 & 24.1 & \multirow[t]{4}{*}{36.799} & \multirow[t]{4}{*}{$\mathrm{P}=0.028$} \\
\hline & $\begin{array}{l}\text { twice a } \\
\text { week }\end{array}$ & 260 & 81 & 31.2 & & \\
\hline & Weekly & 354 & 140 & 39.5 & & \\
\hline & $\begin{array}{l}\mathrm{T} \text { w o } \\
\text { w e e k } \mathrm{k} \\
\mathrm{a} \quad \mathrm{n} \quad \mathrm{d} \\
\text { more }\end{array}$ & 107 & 38 & 35.5 & & \\
\hline \multirow{2}{*}{$\begin{array}{l}\text { School } \\
\text { health } \\
\text { teacher }\end{array}$} & $\begin{array}{l}\text { There } \\
\text { was }\end{array}$ & 568 & 150 & 26.4 & \multirow[t]{2}{*}{19.42} & \multirow[t]{2}{*}{$\mathrm{P}=0.000$} \\
\hline & $\begin{array}{l}\text { There } \\
\text { was not }\end{array}$ & 232 & 128 & 55.2 & & \\
\hline Dander & $\mathrm{Had}$ & 292 & 108 & 37.0 & 6.068 & $\mathrm{P}=0.314$ \\
\hline
\end{tabular}
study Moradi et $\mathrm{al}^{[29]}$ (2009), it was observed that in $\neg$ festation rates among children with educated parents were lower than of head lice infestation and the level of parenting education. In

\section{Discussion}

The overall prevalence of head louse infestation in the city of Garmsar was approximately $34.75 \%$. This prevalence in primary and guidance schools students was $34.4 \%$ and $36 \%$, respectively. As a result infestation rate in this study indicated that head lice were considered a vital public health problem among the students of both schools, especially among guidance school students than primary school students in Garmsar city. The results of studies in worldwide revealed different findings about head lice among primary school students. The prevalence of infestation to head louse in primary schools in Korea was $4.1 \%$. In this study $6.5 \%$ of girls and $1.9 \%$ of boys had head lice infection $^{[18]}$ (Oh et al. 2010). In Turkey, the overall prevalence of head lice infestation was $13.1 \%$. Pediculosis was more frequent in girls $(25.2 \%)$ than in boys $(0.86 \%)(\mathrm{p}<0.001)^{[19]}$ (Gulgun et al. 2013). In Thailand, $23.32 \%$ of schoolchildren aged 5-12 years old are infested to head lice, and infestation rate was higher in girls $(47.12 \%)$ than in boy $(0 \%)^{[5]}$ (Rassami and Soonwera 2012). Studies conducted in elementary schools in Fayoum and Minofiya Governorates, Egypt reported a prevalence rate of $16.7 \%$ where the prevalence in girls was $25.8 \%$ more than boys $^{[20]}$ (El Raheem et al. 2015). In India, $16.59 \%$ of students are infested to head lice and prevalence rate in girls was $20.42 \%$ in contrast to boys with $13.86 \%{ }^{[21]}$ (Khokhar 2002). The prevalence of head louse infestation among primary school students in all studies mentioned in cities of Iran is different, for example Fars 1\% ${ }^{[22]}$ (Davarpanah et al. 2009), Kerman 3.8\% ${ }^{[23]}$ (Kamiabi and Nakhaei 2005), Babol 1.65\% ${ }^{[24]}$ (Zabihi et al. 2005), Aran and Bidgol $0.47 \%{ }^{[25]}$ (Doroodgar et al. 2014) and the highest infection rate in girls has been reported. This result can be due to behavioral differences between the two sexes, including short hair of boys compared to girls, the covering of the head and the headscarf in girls, the harshness of the games, and the lack of intimacy of boys and other factors. Perhaps one of the reasons for the high prevalence of this health problem in Garmsar schools is factors such as unfavorable geographical and climatic conditions $^{[26]}$ (Kasiri et al. 2009). Similar studies in Ahwaz and Zabul have reported infection rates of $11 \%$ and $29.4 \%$, respectively ${ }^{[26], 27}$ (Zareban et al. 2006; Kasiri et al. 2009). One of the person characteristic contributing to the higher rate of infestation in girls is the length of their hair. At the present study, statistical analysis showed significant differences among pediculosis and style and hair length of students. Therefore, one of the most important causes of head lice infestation in girls is long hair. While, Service believes that the rate of head louse infestation doesn't depend on the length of hair ${ }^{[25]}$ (Doroodgar et al. 2014). The many studies indicated that head lice are spread through close contact, children's play and frequent contact of their head or use of scarves, hats, combs, hair brushes and other accessories can transmit head lice which were in contrast with the results from this study ${ }^{[28]}$ (Dehghanzadeh et al. 2015). The results of this study showed that there is not a significant relationship between the use of common personal belongings and the increase in the
incidence of lice in girl's students. According to most researches 
Citation: Ghobakhloo, S. Survey the Prevalence of Pediculosis Capitis and its Associated Risk Factors among Girls' Schools Students in Garmsar City, Semnan Province (Iran). (2018) Lett Health Biol Sci 3(1): 20- 26.

that among children with uneducated parents ${ }^{[29]}$ (Moradi et al. 2009). In the present study, there was a higher rate of infection in students whose educational levels of mother's were elementary and illiterate whereas there was no significant association between educational levels of father's and infestation. It seems that if the size of the household population is high, parents are less able to address the health status of their children. As a result, crowded households are expected to have close contacts between individuals and, consequently, higher prevalence rates. But in this study, there was no significant relationship between the number of family members and the prevalence. On the contrary, the findings of this study are in contrast with the results of Kasiri et $\mathrm{al}^{[26]}$. (2009). The cases of head lice infestation in the first and second grade were somewhat higher than other grade, so that there was significant relationship between grade and prevalence. In agreement with the present results, Rafinejad et $\mathrm{al}^{[30]}$. (2006) and Farzinnia et $\mathrm{al}^{[31]}$. (2004) had reported, a significant association there was between grade and prevalence. Our study also showed significant association between the accesses to bathing intervals per week, combing intervals and infestation rate. Surveys conducted at the Gonabad, Gilan and Ahvaz showed a significant association between bathing intervals per week and head lice infestation ${ }^{[30,29]}$ (Rafinejad et al. 2006; Kasiri et al. 2009). In studies conducted in Qom and Sanandaj, a significant relationship was observed between pediculosis and hair brushes ${ }^{[32,33]}$ (Davari and Yaghmaei 2005; Saghafipour et al. 2012). Due to the fact that head lice stick to the hair and release allergenic substances, itching is the most common symptom of lice infestation and so that is the good sign for detection of lice infestation in female students. Our findings revealed that of the 12 schools studied, about $46 \%$ of the students infested to head lice did not have a health teacher at their school. There was a significant difference in the prevalence of head lice among students with health teacher and students without a health teacher. The reason for this may be due to the poor performance of health educators in controlling the health of students or their ineffective presence in some schools in the country. This study also revealed that students in families with low economic status were definitely in a higher position in terms of having head lice relative to higher income families. At the present study, we also surveyed the prevalence of head lice infestation by parent's occupation. The prevalence of lice infestation in students with farmer father was not significant $(\mathrm{P}<0.056)$.In agreement, no significant association between the father's job and infestation was found in the Hamadan Province[10] (Nazari et al. 2005) but in similar studies in Sanandaj, Qom and other parts of the world, significant association between pediculosis and job of parents was found ${ }^{[31,32]}$. (Davari and Yaghmaei 2005; Saghafipour 2012) According to the findings of this study, factors such as the presence of health teacher in schools, bathing intervals, combing intervals , access to health services, mothers literacy, type of hair, school grade, and parents' job $(\mathrm{p}<0.05)$ have a significant role in the high prevalence of disease among girls' schools in Garmsar.

\section{Conclusion}

In Iran and many countries in the world, the incidence of head lice is highlighted as a health problem in schools students. On the other hand, several studies have shown that the prevalence of pediculosis decrease with increasing life standards i.e. with high income, parental education level, accessibility and consumption of clean water, health education and better health care system. Therefore, in order to cope with this problem, the participation of various government bodies such as Ministry of Education, Ministry of Health, the City Council, teachers community and most importantly, the students and their families will be required.

Conflict of interest statement: We declare that we have no conflict of interest.

Acknowledgements: We want to express our special appreciation of Semnan University of Medical Sciences for cooperation and providing facilities to this work. The authors are indebted to the authorities of all participating schools for their co-operation. Grate full thanks of the survey team, Dr. Bahram Ghods and Education authorities that participated in our study. Special thanks to my husband, Saeed Purshahrab, for her help, encouragement and patience.

\section{References}

1. Burkhart, C.N., Burkhart, C.G. Fomite transmission in head lice. (2007) J Am Acad Dermatol 56(6): 1044-1047. PubMed | Crossref $\mid$ Others

2. Kurt, O., Balcıoğlu, I.C., Limoncu, M.E., et al. Treatment of head lice (Pediculus humanus capitis) infestation: Is regular combing alone with a special detection comb effective at all levels? (2015) Parasitol Res 114(4): 1347-1353.

PubMed | Crossref | Others

3. Eroglu, F., Basaran, U., Kürklü, C.G., et al. Pediculosis capitis is a growing neglected infestation due to migration in southeast Turkey. (2016) Parasitol Res 115(6): 2397-2401. PubMed | Crossref | Others

4. Gallardo, A., Cueto, G.M., Picollo, M. Pediculus humanus capitis (head lice) and Pediculus humanus humanus (body lice): response to laboratory temperature and humidity and susceptibility to monoterpenoids. (2009) Parasitol Res 105(1): 163-167.

PubMed | Crossref | Others

5. Rassami, W., Soonwera, M. Epidemiology of pediculosis capitis among schoolchildren in the eastern area of Bangkok, Thailand. (2012) Asian Pac J Trop Biomed 2(11): 901904.

\section{PubMed | Crossref | Others}

6. Soonwera, M. Efficacy of herbal shampoo base on native plant against head lice (Pediculus humanus capitis De Geer, Pediculidae: Phthiraptera) in vitro and in vivo in Thailand. (2014) Parasitol Res 113(9): 3241-3250. PubMed | Crossref | Others

7. Shirvani, G.Z., Shokravi, A.F., Ardestani, M.S. Evaluation of a health education program for head lice infestation in fe- 
male primary school students in Chabahar City, Iran. (2013)

Arch Iran Med 16(1): 42.

PubMed | Crossref | Others

8. Gur, I., Schneeweiss, R. Head lice treatments and school policies in the US in an era of emerging resistance. (2009) Pharmacoeconomics 27(9): 725-734.

PubMed | Crossref | Others

9. Falagas, M.E., Matthaiou, D.K., Rafailidis, P.I., et al. Worldwide prevalence of head lice. (2008) Emerg Infect Dis 14(9): 1493-1494.

PubMed | Crossref | Others

10. Omidi, A., Khodaveisi, M., Moghimbeigi, A., et al. Pediculosis capitis and relevant factors in secondary school students of Hamadan, West of Iran. (2013) J Res Health Sci 13(2): 176-180.

PubMed |Crossref $\mid$ Others

11. Nazari, M., Saidijam, M. Pediculus capitis infestation according to sex and social factors in Hamedan, Iran. (2006) Pak J Biol Sci 10(19): 3473-3475.

PubMed | Crossref | Others

12. Soleymanizadeh, L., Sharifi S.K. The Assessment of Main Factors on the Louse in Primary School Children at Bandar Abbas City Academic Year 99-2000. (2002) Iran J Infect Dis Trop Med 7(19): 79-85. PubMed $\mid$ Crossref $\mid$ Others

13. Tappeh, K.H., Chavshin, A., Hajipirloo, H.M., et al. Pediculosis capitis among primary school children and related risk factors in Urmia, the main city of West Azarbaijan, Iran. (2012) J Arthropod Borne Dis 6(1): 79-85.

PubMed | Crossref | Others

14. Adalatkhah, H., Arshi, S., Sadeghi, H., et al. Prevalence of Pediculosis Capitis among Boarding School Girls in Ardabil, during Academic Year, 2001-2002. (2002) J Ardabil Univ Med Sci 2(4): 36-45.

PubMed $\mid$ Crossref $\mid$ Others

15. Vahabi, A., Shemshad, K., Sayyadi, M., et al. Prevalence and risk factors of Pediculus (humanus) capitis (Anoplura: Pediculidae), in primary schools in Sanandaj City, Kurdistan Province. (2012) Iran Trop Biomed 29(2): 207-211. PubMed |Crossref $\mid$ Others

16. Chouela, E., Abeldaño, A., Cirigliano, M., et al. Head louse infestations: epidemiologic survey and treatment evaluation in Argentinian schoolchildren. (1997) Int J Dermatol 36(11): 819-825.

PubMed | Crossref | Others

17. Frankowski, B.L. American Academy of Pediatrics guidelines for the prevention and treatment of head lice infestation. (2004) Am J Manag Care 10(9 Suppl): S269-S272.
PubMed | Crossref $\mid$ Others

18. Oh, J.M., Lee, I.Y., Lee, W.J., et al. Prevalence of pediculosis capitis among Korean children. (2010) Parasitol Res 107(6): 1415-1419.

PubMed | Crossref | Others

19. Gulgun, M., Balci, E., Karaoglu, A., et al. Pediculosis capitis: prevalence and its associated factors in primary school children living in rural and urban areas in Kayseri, Turkey. (2013) Cent Eur J Public health 21(2): 104-108. PubMed | Crossref $\mid$ Others

20. El Raheem, T.A.A., El Sherbiny, N.A., Elgameel, A., et al. Epidemiological comparative study of pediculosis capitis among primary school children in Fayoum and Minofiya governorates, Egypt. (2015) J Community Health 40(2): 222-226.

PubMed | Crossref | Others

21. Khokhar, A. A study of pediculosis capitis among primary school children in Delhi. (2002) Indian J Med Sci 56(9): 449-452.

PubMed | Crossref | Others

22. Davarpanah, M., Mehrabani, D., Khademolhosseini, F., et al. The prevalence of Pediculus capitis among school children in Fars Province, Southern Iran. (2009) Iran J Parasitol 4(2): 48-53.

PubMed | Crossref $\mid$ Others

23. Kamiabi, F., Nakhaei, F.H. Prevalence of pediculosis capitis and determination of risk factors in primary-school children in Kerman. (2005) East Mediterr Health J 11(5-6): 988-992.

PubMed | Crossref $\mid$ Others

24. Zabihi, A., Jafarian Amiri, S., Rezvani, S., et al. Study of infestation rate of Pediculus capitis in primary school students in Babol city. (2005) J Babol Univ Med Sci 4(28): 88-93. PubMed | Crossref $\mid$ Others

25. Doroodgar, A., Sadr, F., Doroodgar, M., et al. Examining the prevalence rate of Pediculus capitis infestation according to sex and social factors in primary school children. (2014) Asian Pacific Journal of Tropical Disease 4(1): 25-29.

PubMed | Crossref $\mid$ Others

26. Kasiri, H., Rafiee, A., Mohamadi, Z., et al. Epidemiology of pediculus humanus capitis infestation and effective factors in elementary schools of girls Ahvaz city, 2005. (2009) Iran J Infect Dis Trop Med 14(2): 41-45.

PubMed | Crossref $\mid$ Others

27. Zareban, I., Abbaszadeh, M., Moodi, M., et al. Evaluating a health- education program in order to reduce infection to Pediculus Humanus Capitis among female elementary students. (2006) J Zabol Univ Med Sci Health Service 3(1): 
10-15.

PubMed $\mid$ Crossref $\mid$ Others

28. Dehghanzadeh, R., Asghari-Jafarabadi, M., Salimian, S., et al. Impact of family ownerships, individual hygiene, and residential environments on the prevalence of pediculosis capitis among schoolchildren in urban and rural areas of northwest of Iran. (2015) Parasitol Res 114(11): 4295-4303. PubMed | Crossref | Others

29. Moradi, A., Zahirnia, A., Alipour, A., et al. The prevalence of Pediculosis capitis in primary school students in Bahar, Hamadan Province, Iran. (2009) J Res Health Sci 9(1): 4549.

\section{PubMed | Crossref | Others}

30. Rafinejad, J., Nourollahi, A., Javadian, E., et al. Epidemiology of head louse infestation and related factors in school children in the county of Amlash, Gilan Province, 20032004. (2006) Iranian J Epidemiol 2(3): 51-63.

PubMed | Crossref | Others

31. Farzinnia, B., Hanafibejad, A.A., Raeiskarami, S.R., et al. Epidemiology of head lice in primary school girls in Qom, 2002. (2004) Hormozgan University of Medical Sciences 2(8): 103-108.

PubMed | Crossref $\mid$ Others

32. Davari, B., Yaghmaie, R. Prevalence of head lice and its related factors in the primary school students in Sanandaj 1999. (2005) Sci J Kurdistan Univ Med Sci 10(1): 39-45. PubMed $\mid$ Crossref $\mid$ Others

33. Saghafipour, A., Akbari, A., Norouzi, M., et al. The epidemiology of pediculus is humanus capitis infestation and effective factors in elementary schools of Qom Province Girls 2010, Qom, Iran. (2012) Qom Uni Med Sci J 6(3): 46-51. PubMed $\mid$ Crossref $\mid$ Others
Submit your manuscript to Ommega Publishers and we will help you at every step:

- We accept pre-submission inquiries

- Our selector tool helps you to find the most relevant journal

- We provide round the clock customer support

- Convenient online submission

- Thorough peer review

- Inclusion in all major indexing services

- Maximum visibility for your research

Submit your manuscript at

https://www.ommegaonline.org/submit-manuscript 